\title{
Chemotherapy for Metastatic Disease
}

\author{
Takehiro Sejima, Shuichi Morizane, Akihisa Yao, \\ Tadahiro Isoyama and Atsushi Takenaka \\ Division of Urology, Department of Surgery, Tottori University Faculty of Medicine \\ Japan
}

\section{Introduction}

Bladder cancer occurs with a relatively high incidence in industrial nations. For example, bladder cancer is the fourth most common type of cancer in American men. The estimated U.S. incidence in 2008 was 68,810 cases and the mortality was 14,100 cases (Jemal et al., 2008). Of newly diagnosed bladder cancer cases, approximately $70 \%-80 \%$ will present with non muscle-invasive disease. Among such cases, $50 \%-70 \%$ will recur, and $10 \%-30 \%$ will progress to muscle-invasive disease (Soloway et al., 2002; Saad et al., 2002). Radical cystectomy with or without chemotherapy is the standard therapy for muscle-invasive disease; however, some patients will experience metastatic relapse after radical surgery. A few patients present with metastatic disease upon their initial presentation at the hospital. Such advanced bladder cancer remains an incurable terminal disease, and accounts for 3\% of the cancer-related mortality in the United States. Deaths from bladder cancer are mainly related to distant spread; hence, prevention of metastatic disease remains a crucial goal in this disease. Systemic chemotherapy achieves palliation, survival benefit, and occasional long-term remissions. For the last two decades, cisplatin-based combination therapies have evolved as the standard. The MVAC regimen (Sternberg et al., 1988) was reported to demonstrate an impressive complete remission rate of $37 \%$ in advanced urothelial carcinoma (UC), and in a subsequent comparative study was found to be superior to the single agent cisplatin (Saxman et al., 1997). In this chapter, we review the recent progress in chemotherapeutic regimens not only for advanced bladder cancer, but also for advanced UC in the upper urinary tract. We also show current data on the efficacy of combination therapy with gemcitabine and platinum anti-cancer drugs, which is mainly used as a second-line treatment in our institution.

\section{The first successful chemotherapeutic regimen for advanced Urothelial Carcinoma (UC)}

Despite recent developments in anti-cancer drugs, advanced UC remains an incurable disease, with a median survival time of only 12 to 14 months (Jemal et al., 2003). The most reliable treatment option for advanced UC is considered to be combination chemotherapy including a platinum anti-cancer drug. The combination chemotherapy regimen of methotrexate / vinblastine / doxorubicin / cisplatin (MVAC) as reported originally by Sternberg (Sternberg et al., 1988) is currently being used worldwide with superior efficacy. However, MVAC treatment is associated with substantial toxicities and has a toxic death rate of approximately 
3 - 4\% (Sternberg et al., 1989; Loehrer et al., 1992). Therefore, the need for an alternative less toxic combination chemotherapy that can provide efficacy similar or superior to the MVAC regimen has been identified. Gemcitabine, a nucleoside analogue, has demonstrated activity against a range of solid tumors, including metastatic UC (Gatzemeier et al., Moore, 1996; Stadler et al., 1997). In particular, gemcitabine alone has yielded a response rate of $23-29 \%$, with a complete response rate of $4-13 \%$, in both previously treated and untreated metastatic UC patients (Sternberg, 2000). The good activity and toxicity profiles of single-agent gemcitabine treatment and its synergism with cisplatin in pre-clinical models (Peters et al., 1995) led to the development of this combination for the treatment of advanced UC. After obtaining results from phase 2 trials of combination therapy comprising gemcitabine plus cisplatin (GC) as first- or second-line treatment for UC, von der Maase et al. published a large multinational phase 3 trial comparing MVAC with GC therapy, with a total of 405 patients accrued (von der Maase et al., 2000). The final results show that the two regimens are similar in terms of response rate, time to progression and survival. However, the GC combination showed a better safety profile and tolerability than MVAC. The representative randomized trials on MVAC and GC are summarized in Table 1. Carboplatin shares a common mechanism of action with cisplatin, but the two have different pharmacokinetic and dose-limiting toxicities (Van Echo et al., 1989). Patients with UC are often elderly, and frequently have clinical or subclinical renal function impairment. Thus, the substitution of carboplatin for cisplatin offers a promising alternative for these patients. There have been several phase 2 reports showing that gemcitabine / carboplatin achieved clinical results equivalent to those of GC (Xu et al., 2007; Dogliotti et al., 2007). It can thus be speculated that the combination of gemcitabine plus a platinum anti-cancer drug (cisplatin or carboplatin) is currently being used worldwide in the treatment of advanced UC.

\begin{tabular}{|c|c|c|c|c|}
\hline Therapy & $\begin{array}{c}\text { No. of } \\
\text { Patients }\end{array}$ & $\begin{array}{l}\text { Response } \\
\text { Rate/PFS }\end{array}$ & $\begin{array}{l}\text { Median } \\
\text { Survival }\end{array}$ & $\begin{array}{c}\text { Hazard } \\
\text { Ratio/ } P \text { value }\end{array}$ \\
\hline $\begin{array}{c}\text { MVAC } \\
\text { (Sternberg) } \\
\text { High dose } \\
\text { MVAC } \\
\text { (Sternberg) }\end{array}$ & $\begin{array}{l}\quad 263 \\
\text { (MVAC+High } \\
\text { dose MVAC) }\end{array}$ & $\begin{array}{c}50 \%(\text { CR } 9 \%) \\
\text { Med PFS } 8.1 \text { months } \\
64 \%(\text { CR } 21 \%) \\
\text { Med PFS } 9.5 \text { months }\end{array}$ & $\begin{array}{c}14.9 \text { months } \\
\text { (2 year survival } 26.2 \%) \\
\text { (5 year survival } 13.5 \% \text { ) } \\
\quad 15.1 \text { months } \\
\text { (2 year survival } 36.7 \% \text { ) } \\
\text { (5 year survival } 21.8 \% \text { ) }\end{array}$ & $\begin{array}{r}\mathrm{HR}=0.76 \\
P=0.042\end{array}$ \\
\hline $\begin{array}{l}\text { Cisplatin } \\
\text { (Saxman) }\end{array}$ & 122 & $\begin{array}{c}\text { PR } 12 \% \\
\text { Med TTP } 10 \text { months }\end{array}$ & 8.2 months & $P=\mathbf{0 . 0 0 0 2}$ \\
\hline $\begin{array}{c}\text { MVAC } \\
\text { (Saxman) }\end{array}$ & 133 & $\begin{array}{c}\text { PR } 39 \% \\
\text { Med TTP } 4.3 \text { months }\end{array}$ & 12.5 months & \\
\hline $\begin{array}{l}\text { MVAC } \\
\text { (Von der } \\
\text { Maase) }\end{array}$ & 202 & $\begin{array}{c}46 \% \\
\text { Med PFS } 8.3 \text { months }\end{array}$ & 15.2 months & $\begin{array}{c}P=\mathbf{0 . 7 5} \\
\mathrm{HR}=\mathbf{0 . 0 4 2}\end{array}$ \\
\hline $\begin{array}{l}\quad \text { GC } \\
\text { (Von der } \\
\text { Maase) }\end{array}$ & 203 & $\begin{array}{c}49 \% \\
\text { Med.PFS } 7.7 \text { months }\end{array}$ & 14.0 months & \\
\hline
\end{tabular}

Table 1. Summary of representative randomized trials exploring chemotherapy in metastatic urothelial cancer 


\section{The efficacy and safety of combination chemotherapy with gemcitabine and a platinum anti-cancer drug. A regimen mainly used as second-line chemotherapy for patients with advanced UC at Tottori university hospital}

Our original data regarding the effects of combination therapy with gemcitabine plus platinum anti-cancer drug as second-line chemotherapy for cases of advanced UC are described below. These data were gathered mainly as a result of limitations in the Japanese insurance system, which until recently did not cover the use of gemcitabine for the treatment of UC. That is, before February 2009, the use of gemcitabine was not allowed for general use in Japan, and thus only referral academic institutions such as ours were able to conduct gemcitabine therapy. Because the incurable rate is still high in advanced UC patients to date in spite of the medical progress of many anti-cancer drugs in Japan and other countries, physicians often encounter patients with advanced UC who need to undergo more than one kind of chemotherapy. Therefore sequential data of second-line chemotherapy like ours is considered to be useful for urological oncologists worldwide. In this paragraph, the therapeutic data for cases of upper urinary tract UC are also included. This book is of course about bladder cancer; however, it is often difficult to isolate the therapeutic data for bladder cancer from the data for all cases of UC. Therefore, we regret that we cannot describe the results for bladder cancer data specifically.

\subsection{Patients' characteristics}

From December 2004 until September 2011, 30 patients received the combination chemotherapy of gemcitabine plus a platinum anti-cancer drug (cisplatin or carboplatin) at

\begin{tabular}{|c|c|c|}
\hline \multirow{2}{*}{$\begin{array}{l}\text { Characteristics } \\
\text { No. of patients }\end{array}$} & \multicolumn{2}{|c|}{ No. of patients $(\%)$} \\
\hline & 30 & $(100 \%)$ \\
\hline Median age, yr (range) & 72 & $(52-83)$ \\
\hline \multicolumn{3}{|l|}{ Gender } \\
\hline Male & 23 & $(76.7 \%)$ \\
\hline Female & 7 & $(23.3 \%)$ \\
\hline \multicolumn{3}{|l|}{ Previous therapy } \\
\hline None & 4 & $(13.3 \%)$ \\
\hline Methotrexate/Epirubicin/Cisplatin (MEC) & 14 & $(46.7 \%)$ \\
\hline Methotrexate/Epirubicin/Carboplatin (modified MEC) & 9 & $(30.0 \%)$ \\
\hline Etoposide/ Cisplatin & 1 & $(3.3 \%)$ \\
\hline Radiation + Intraarterial chemotherapy & 2 & $(6.7 \%)$ \\
\hline \multicolumn{3}{|l|}{ Primary urothelial tumor site } \\
\hline Bladder & 9 & $(30.0 \%)$ \\
\hline Renal pelvis $\sim$ ureter & 21 & $(70.0 \%)$ \\
\hline Advanced disease at first visit & 7 & $(23.3 \%)$ \\
\hline Recurrence after surgery for primary tumor & 23 & $(76.7 \%)$ \\
\hline \multicolumn{3}{|l|}{ Site of metastasis or recurrence, or invasion from primary tumor } \\
\hline Lung & 6 & $(20.0 \%)$ \\
\hline Lymph node & 18 & $(60.0 \%)$ \\
\hline Localrecurrence & 5 & $(16.7 \%)$ \\
\hline Bone & 2 & $(6.7 \%)$ \\
\hline
\end{tabular}

Table 2. Patient characteristics 
our institution. All patients were evaluated for efficacy and for toxicity. The pretreatment characteristics of the patients are listed in Table 2.23 patients $(77 \%)$ had previously received combination chemotherapy of methotrexate / epirubicin / cisplatin (MEC).

\subsection{Treatment plan}

In the first cycle of the therapy, the creatinine clearance (Ccr) ( $\mathrm{ml} / \mathrm{min}$ ) of each patient was measured prior to initiation of the therapy. In the patients with $\mathrm{Ccr}>60$, cisplatin was administered, while in those with $\mathrm{Ccr}<60$, carboplatin was administered as the platinum anti-cancer drug. Gemcitabine $\left(1,000 \mathrm{mg} / \mathrm{m}^{2}\right)$ was given by intravenous infusion over $30-$ $60 \mathrm{~min}$ on days 1,8 , and 15 . Cisplatin $\left(70 \mathrm{mg} / \mathrm{m}^{2}\right)$ was given by intravenous infusion over $30-60$ min on day 2 in the cisplatin group, whereas carboplatin dosed to an AUC of 5 was given by intravenous infusion over $30-60$ minutes on day 2 in the carboplatin group. Basically, each cycle consisted of 21 days. However, an extension of the days in each cycle was permitted based on the judgment of the physician in charge if any severe adverse events were noted. All toxicities were recorded according to the National Cancer Institute Common Toxicity Criteria (NCI-CTC) version 3.0. Dose adjustment during the treatment was based on hematological and non-hematological assessment of toxicities. In the hematological assessment of toxicities, leukocyte and platelet counts were generally measured weekly. For cases where leukocytes $<2,000 / \mathrm{mm}^{3}$ or platelets $<75,000 / \mathrm{mm}^{3}$, or where there was evidence of bleeding, gemcitabine was omitted. No new cycle was started unless leukocytes were $>2,000 / \mathrm{mm}^{3}$ and platelets were $>75,000 / \mathrm{mm}^{3}$. The platinum anticancer drug dose was reduced by $50 \%$ for grade 2 neurotoxicity, omitted for grade 3 , and stopped for grade 4 . For renal toxicity, the dose of platinum anti-cancer drug was reduced by $50 \%$ for Cor $50-59$, and omitted for Ccr $<50$. For other grade 3 non-hematological toxicities (except nausea, vomiting, and alopecia), gemcitabine and platinum anti-cancer drug doses were reduced by $50 \%$ or omitted per the physician in charge. For grade 4 toxicities, doses were reduced by $50 \%$ or stopped (unless the patient was responding to the therapy).

\subsection{Dose administration}

The median number of consecutive cycles per patient was 3 (range: $1-7$ ). 16 patients (53\%) underwent more than 3 cycles of the therapy. Cisplatin was administered in 12 patients $(40 \%)$, while carboplatin was administered in 18 patients $(60 \%)$ as the platinum anti-cancer drug (Table 3).

\subsection{Efficacy}

All 30 patients were assessed with regard to clinical outcome and treatment efficacy according to RECIST criteria at the end of the study. With regard to clinical outcome (Table $3)$, we observed $2(7 \%)$ cases of complete response (CR) and 7 (23\%) cases of partial response (PR), with an overall response rate (ORR) of 30\%. The visceral field of metastasis or relapse in patients of CR and PR was the lungs in 3 cases, lymph nodes in 5 cases, and local relapse (post-nephroureterectomy) in 1 case. There were no cases with responses in other visceral fields such as bone. Stable disease (SD) was identified in 10 patients (33\%), and progressive disease (PD) in 9 patients (30\%). 2 patients $(7 \%)$ were not evaluated. The median time to follow-up was 11.7 months (range: 0.8 - 65.8 months). The median overall survival (OS) was 11.1 months. Kaplan-Meier curves for OS are shown in Fig. 1. 


\begin{tabular}{lcc}
\hline & & No. of patients $(\%)$ \\
\hline No. of chemotherapy cycles & 1 & $6(20.0)$ \\
& 2 & $8(26.7)$ \\
& 3 & $10(33.3)$ \\
More than 4 & $6(20.0)$ \\
Platinum drug & Cisplatin & $12(40.0)$ \\
Carboplatin & $18(60.0)$ \\
& & \\
Efficacy according to RECIST & CR & $7(6.7)$ \\
& PR & $10(33.3)$ \\
& SD & $9(30.0)$ \\
PD & $2(6.7)$ \\
NE & $2(6.7)$ \\
Outcome & NED & $20(66.6)$ \\
\hline
\end{tabular}

Table 3. Treatment profile and efficacy

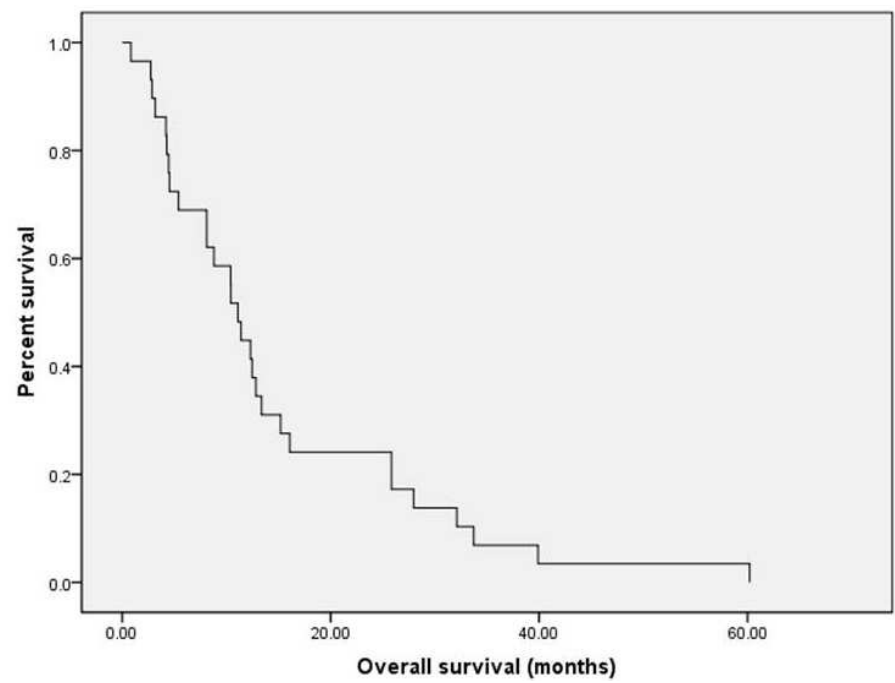

Fig. 1. Overall survival rate of all 30 patients with advance UC treated at Tottori University Hospital

\subsection{Toxicity}

Only 1 patient discontinued the therapy simply for reasons of toxicity; this patient showed a Grade 2 allergic reaction to gemcitabine, which was administered on day 15 . Since this patient eventually received one whole cycle of the therapy, we assessed the efficacy of the 
treatment as such. Grade 3 / 4 neutropenia was the most frequent toxicity, occurring in $63 \%$ of the patients. Grade 3 / 4 thrombocytopenia was also a frequent toxicity, occurring in $57 \%$ of the patients. Grade 3 / 4 non-hematologic toxicities included nausea and vomiting in 1 patient $(3 \%)$. Major toxicities according to NCI-CTC are summarized in Table 4 . No other types of major toxicities such as nephrotoxicity or neurotoxicity were observed in any patients. In order to analyze the cumulative damage due to hematologic side effects, the nadir values of blood counts were analyzed. The nadir values of hemoglobin and the nadir counts of leukocytes and platelet cells in the first cycle were practically the same as those in the other progressive cycles. In other words, hematological toxicities were not enhanced by the progressive repetition of cycles (data not shown).

\begin{tabular}{lllll}
\hline & \multicolumn{5}{c}{ No. of patients (\%) } \\
& Grade 1 & Grade 2 & Grade 3 & Grade 4 \\
\hline Neutropenia & $4(13.3)$ & $6(20.0)$ & $16(53.3)$ & $3(10.0)$ \\
Anemia & $3(10.0)$ & $13(43.3)$ & $9(30.0)$ & $4(13.3)$ \\
Thrombocytopenia & $6(20.0)$ & $4(13.3)$ & $8(26.7)$ & $9(30.0)$ \\
Vomiting & $3(10.0)$ & $2(6.7)$ & $1(3.3)$ & $0(0)$ \\
Allergy & $0(0)$ & $1(3.3)$ & $0(0)$ & $0(0)$ \\
\hline
\end{tabular}

Table 4. Mayor toxicities according to NCI-CTC

\subsection{Conclusions}

The efficacy of gemcitabine plus a platinum anti-cancer drug as a second-line chemotherapy for advanced UC was found to be modest. The toxicity of the therapy was tolerable despite damage from previous chemotherapy and repeated cycles. The present data, obtained as a result of particular limitations in the medical insurance industry in Japan, will be helpful when considering the best course of second-line chemotherapy for cases of advanced UC in the future.

\section{Is there any effective combination chemotherapy except MVAC or GC for advanced UC? \\ - The combination therapy of methotrexate / epirubicin / cisplatin (MEC) -}

The combination chemotherapy of methotrexate, epirubicin and cisplatin (MEC) was mainly developed in Japan for the purpose of establishing a regimen less toxic than MVAC but with equal efficacy. Several academic Japanese institutions including the Japanese Urothelial Cancer Research Group promoted a randomized trial comparing MEC and MVAC (Kuroda et al., 1998). Total of 89 patients were assigned to three groups receiving either standard MEC (SMEC), dose-intensified MEC (I-MEC) or MVAC. The S-MEC regimen consisted of methotrexate $\left(30 \mathrm{mg} / \mathrm{m}^{2}\right)$, epirubicin $\left(50 \mathrm{mg} / \mathrm{m}^{2}\right)$ and cisplatin $\left(100 \mathrm{mg} / \mathrm{m}^{2}\right)$, and that of the I-MEC regimen was methotrexate $\left(36 \mathrm{mg} / \mathrm{m}^{2}\right)$, epirubicin $\left(60 \mathrm{mg} / \mathrm{m}^{2}\right)$ and cisplatin $(120$ $\mathrm{mg} / \mathrm{m}^{2}$ ). In both groups, methotrexate was administered on day 1 and 15, epirubicin was administered on day 1 , and cisplatin was administered on day 2. In the I-MEC group, G-CSF 
$(2 \mu \mathrm{g} / \mathrm{kg})$ was administered from day 3 until day 12 routinely. The response rates $(\mathrm{CR}+\mathrm{PR})$ were $52 \%$ with S-MEC, $76 \%$ with I-MEC and $47 \%$ with MVAC. All of the adverse events were rendered tolerable in the S-MEC and I-MEC groups through the use of G-CSF agents. We had been utilizing MEC as a first choice therapy until 2008 in our institution because it was less toxic than but as effective as MVAC. As a matter of fact, most of the patients in our study of second-line combination chemotherapy with gemcitabine and the platinum anti-cancer drugs described above had been receiving MEC as the first line chemotherapy at other institutions.

\section{Prevention of micro metastasis and effort of tumor reduction by neoadjuvant chemotherapy at radical cystectomy}

In T2-4 (invasive) bladder cancer, neoadjuvant chemotherapy with MVAC or cisplatin, methotrexate, and vinblastine has demonstrated significant progression-free survival (PFS) and OS benefit in several randomized trials. One representative trial is the Intergroup 8710 trials reported by Grossman et al. in which cystectomy alone was compared with neoadjuvant MVAC followed by radical cystectomy. The group receiving neoadjuvant chemotherapy had an increased likelihood of eliminating residual cancer in the cystectomy specimen (pT0) and had an associated improved survival. Moreover, neoadjuvant chemotherapy did not adversely affect the patient's chance of undergoing a cystectomy and did not increase the risk of postoperative complications (Grossman et al., 2003). In the combined analysis of 2 Nordic studies, neoadjuvant platinum-based combination chemotherapy was associated with an $8 \%$ increase in survival at 5 years (Sherif et al., 2004). A meta-analysis of randomized controlled trials demonstrated a survival benefit to receiving neoadjuvant chemotherapy (Winquist et al., 2004). Carboplatin-based regimens have been evaluated in the neoadjuvant setting only in phase 2 trials, and hence their use in the neoadjuvant or adjuvant setting cannot be recommended (Smith et al., 2008; deVele White et al., 2009). The studies of adjuvant chemotherapy have demonstrated conflicting results. They have had design flaws and small sample sizes and are therefore underpowered to give a conclusive answer regarding the benefits.

\section{Other recent chemotherapeutic regimens including taxanes}

The taxanes are diterpenes produced by the plants of the genus Taxus (yews), and include such compounds as docetaxel and paclitaxel, the latter of which was originally derived from the Pacific yew tree. The principal mechanism of action of the taxane class of drugs is the disruption of microtubule function. Microtubules are essential to cell division, and taxanes stabilize GDP-bound tubulin in the microtubule, thereby inhibiting the process of cell division. Thus, in essence, taxanes are mitotic inhibitors. Both paclitaxel and docetaxel have been studied as chemotherapeutic agents for metastatic bladder cancer. Paclitaxel-based regimens in combination with either cisplatin or carboplatin have been evaluated with response rates between $16 \%$ and $36 \%$ and median survival ranging from 6 to 10 months depending on the characteristics of the patients enrolled and whether they are ciplatinsensitive or a refractory population (Vaishampayan et al., 2005; Uhm et al., 2007). A phase 3 study comparing docetaxel and cisplatin (DC) with G-CSF versus MVAC with G-CSF found MVAC to be more effective than DC for metastatic cancer; MVAC demonstrated both a superior median time to progression (9.4 vs 6.1 months; $P=0.003$ ) and median survival time (14.2 vs 9.3 months; $P=0.026$ ) (Bamias et al., 2004). Other recent representative reports of taxanes with cisplatin therapy are shown in Table 5 . Antifolates such as trimetrexate and 
premetrexed have been better tolerated with promising response rates and should be promising for future evaluation (Witte et al. 1994; Sweeney et al., 2006). Oxaliplatin-based regimens have been evaluated and also shown to be of modest benefit (Carles et al., 2007).

\begin{tabular}{llccccccc}
\hline \multirow{2}{*}{ Author } & Previous & \multicolumn{2}{c}{ Dose $\left(\mathrm{mg} / \mathrm{m}^{2}\right)$} & No. of & Efficacy $(\%)$ & CR rate & Median \\
& therapy & Cisplatin & Taxane & Cases & (CR + PR) & (\%) & sturvival (M) \\
\hline Dreicer & None & 75 & $175(\mathrm{P})$ & 52 & 50 & 8 & 10.6 \\
\multirow{2}{*}{ Burch } & None & 70 & $135(\mathrm{P})$ & 34 & 70 & 32 & 13 \\
Sengelov & None & 75 & $75(\mathrm{D})$ & 25 & 60 & 26 & 13.6 \\
\multirow{2}{*}{ Dimopoulos } & None & 75 & $75(\mathrm{D})$ & 66 & 52 & 12 & 8 \\
\hline
\end{tabular}

P, Paclitaxel; D, Docetaxel

Table 5. Recent representative reports of taxanes with cisplatin therapy for advanced urotherial cancer

\section{Role of targeted therapies in bladder cancer}

The actual clinical advent of targeted therapies has been slower in UC, as compared to other solid tumors due to large variations in histology worldwide, as well as the difficulty in accruing to clinical trials with this malignancy. Vaishampayan et al. evaluated and reported the frequency of overexpression of Her-2 in bladder cancer and correlated with the Her-2 expression in metastatic sites. Interestingly, the overexpression of her-2 by immunohistochemistry (IHC) (2+ or $3+)$ was $37 \%$ in primary bladder tumor tissue, the expression in metastatic sites such as lymph nodes was $63 \%$ and the expression in visceral metastases was $86 \%$ (Vaishampayan, 2009). $45 \%$ of Her-2/neu-negative primaries had Her2/neu-positive lymph node metastases, while $92 \%$ of Her-2-positive primary tumors were associated with Her-2-positive metastasis. This finding suggested that Her-2 overexpression could be a useful therapeutic target for advanced UC. Hence, a phase 2 trial was conducted and reported evaluating the role of trastuzumab with chemotherapy in metastatic UC. An extremely promising $70 \%$ response rate and a favorable median survival of 14 months were noted despite $55 \%$ of the patients having visceral metastases (Hussain et al., 2007). Another novel approach using molecular targeted therapy for advanced UC patients is the combination therapy of bevacizumab and chemotherapeutic agents. A phase 2 study of bevacizumab in combination with cisplatin and gemcitabine in metastatic or locally advanced bladder cancer involving 36 patients showed a complete response in 6 $(17 \%)$, and a partial response in 18 (50\%); this combination is now being studied in a phase 3 trial (Dovedi \& Davies, 2009; Hahn et al., 2011). Another study with anti-angiogenic therapy is the evaluation of sunitinib in a placebo-controlled double-blind trial with the goal of sustaining or prolonging response, after initial chemo-therapy in advanced bladder cancer (Bradley et al., 2007). Epithelial growth factor receptor has also been identified as an exciting target in UC. The over-expression of EGFR by IHC is noted in about $92 \%$ (35 of 38) of the bladder cancer cases at Wayne State University; however, its association with survival 
outcome has not been established (Bellmunt et al., 2003). Given the possibility of EGFRtargeted therapy, a phase 2 randomized trials of cisplatin and gemcitabine with or without cetuximab (a monoclonal antibody to EGFR) is ongoing as a frontline therapy for metastatic UC. Current and future additional trials of targeted therapy are listed in Table 6.

\begin{tabular}{|c|c|c|}
\hline First line for metastatic disease & Therapy & Organization \\
\hline \multicolumn{3}{|l|}{ (not renal insufficiency) } \\
\hline Phase II & $\mathrm{GC}+\mathrm{BVZ}$ & CALGB \\
\hline Phase II & GC + Sorafenib & MSKCC, EORTC \\
\hline Phase I & GC + Lapatinib & EORTC \\
\hline \multicolumn{3}{|l|}{$\begin{array}{l}\text { First line metastatic disease } \\
\text { (renal insufficiency) }\end{array}$} \\
\hline Phase II & GEM + CBDCA + BVZ & MSKCC \\
\hline Phase II & Sunitinib & SOGUG \\
\hline \multicolumn{3}{|l|}{$\begin{array}{l}\text { Second line } \\
\text { (single agent) }\end{array}$} \\
\hline Phase II & Sunitinib & MSKCC \\
\hline Phase II & Sunitinib randum & U. Michigan \\
\hline Phase II & Sorafenib & PMH/SWOG \\
\hline $\begin{array}{l}\text { GC, gemcitabine + cisplatin; BVZ, beva } \\
\text { CALGB, Cancer and Leukemia Group B } \\
\text { ORTC, European Organization for Res } \\
\text { Oncology Genitourinary Group; U. Mic } \\
\text { Hospital; SWOG, Southwest Oncology }\end{array}$ & $\begin{array}{l}\text { MSKCC, Memorial Sloan-Ke } \\
\text { rch and Treatment of Cance } \\
\text { gan, University of Michigan } \\
\text { oup }\end{array}$ & $\begin{array}{l}\text { BDCA, carboplatin; } \\
\text { ering Cancer Center; } \\
\text { SOGUG. Spanish } \\
\text { PMH, Princess Marga }\end{array}$ \\
\hline
\end{tabular}

Table 6. Current and future trial with targeted therapy

\section{Conclusions}

Since the breakthrough progress of development MVAC chemotherapy by Sternberg for advanced UC patients, the survival of such patients has been prolonged compared with those of untreated patients. However, despite the development of anti-cancer drugs, metastatic bladder cancer is still not considered a curable disease. Numerous efforts to achieve improved curability are going, including investigations into molecular targeted therapy, which has just been developed as a breakthrough treatment for patients with advanced renal cell carcinoma in the same field of urologic oncology.

\section{References}

Bamias A, Aravantinos G, Deliveliotis C, Bafaloukos D, Kalofonos C, Xiros N, Zervas A, Mitropoulos D, Samantas E, Pectasides D, Papakostas P, Gika D, Kourousis C, Koutras A, Papadimitriou C, Bamias C, Kosmidis P, Dimopoulos MA; Hellenic Cooperative Oncology Group (2004): Docetaxel and cisplatin with granulocyte colony-stimulating factor (G-CSF) versus MVAC with G-CSF in advanced urothelial carcinoma: a multicenter, randomized, phase III study from the Hellenic Cooperative Oncology Group. J Clin Oncol: Jan 15;22(2):pp. 220-228. Epub 2003 Dec 9. Erratum in: J Clin Oncol: May 1;22(9): pp. 1771. PMID: 14665607 
Bellmunt J, Hussain M, Dinney CP (2003): Novel approaches with targeted therapies in bladder cancer. Therapy of bladder cancer by blockade of the epidermal growth factor receptor family. Crit Rev Oncol Hematol: 46(Suppl): pp. 85-104. PMID: 12850530

Bradley DA, Dunn R, Nanus D, Stadler W, Dreicer R, Rosenberg J, Smith DC, Hussain M (2007): Randomized, double-blind, placebo-controlled phase II trial of maintenance sunitinib versus placebo after chemotherapy for patients with advanced urothelial carcinoma: scientific rationale and study design. Clin Genitourin: Dec;5(7): pp. 460463. PMID: 18272031

Burch PA, Richardson RL, Cha SS, Sargent DJ, Pitot HC 4th, Kaur JS, Camoriano JK (2000): Phase II study of paclitaxel and cisplatin for advanced urothelial cancer. J Urol: Nov;164(5): pp. 1538-1542. PMID: 11025699

Carles J, Esteban E, Climent M, Font A, Gonzalez-Larriba JL, Berrocal A, Garcia-Ribas I, Marfa X, Fabregat X, Albanell J, Bellmunt J; Spanish Oncology Genito Urinary Group Study Group (2007): Gemcitabine and oxaliplatin combination: a multicenter phase II trial in unfit patients with locally advanced or metastatic urothelial cancer. Ann Oncol: Aug;18(8): pp. 1359-1362. PMID: 17693649

deVere White RW, Lara PN Jr, Goldman B, Tangen CM, Smith DC, Wood DP Jr, Hussain $\mathrm{MH}$, Crawford ED (2009): A sequential treatment approach to myoinvasive urothelial cancer: a phase II Southwest Oncology Group Trial (S0219). J Urol: Jun;181(6): pp. 2476-2480; discussion 2480-2481. Epub 2009 Apr 16. PMID: 19371909

Dimopoulos MA, Bakoyannis C, Georgoulias V, Papadimitriou C, Moulopoulos LA, Deliveliotis C, Karayannis A, Varkarakis I, Aravantinos G, Zervas A, Pantazopoulos D, Fountzilas G, Bamias A, Kyriakakis Z, Anagnostopoulos A, Giannopoulos A, Kosmidis P (1999): Docetaxel and cisplatin combination chemotherapy in advanced carcinoma of the urothelium: a multicenter phase II study of the Hellenic Cooperative Oncology Group. Ann Oncol: Nov;10(11): pp. 1385-1388. PMID: 10631471

Dogliotti L, Cartenì G, Siena S, Bertetto O, Martoni A, Bono A, Amadori D, Onat H, Marini L (2007): Gemcitabine plus cisplatin versus gemcitabine plus carboplatin as first-line chemotherapy in advanced transitional cell carcinoma of the urothelium: results of a randomized phase 2 trial. Eur Urol: Jul;52(1): pp. 134-141. PMID: 17207911

Dovedi SJ, Davies BR (2009): Emerging targeted therapies for bladder cancer: a disease waiting for a drug. Cancer Metastasis Rev: Dec;28(3-4): pp. 355-367. PMID: 19997963

Dreicer R, Manola J, Roth BJ, Cohen MB, Hatfield AK, Wilding G (2000): Phase II study of cisplatin and paclitaxel in advanced carcinoma of the urothelium: an Eastern Cooperative Oncology Group Study. J Clin Oncol: Mar;18(5): pp. 1058-1561. PMID: 10694557

Gatzemeier U, Shepherd FA, Le Chevalier T, Weynants P, Cottier B, Groen HJ, Rosso R, Mattson K, Cortes-Funes H, Tonato M, Burkes RL, Gottfried M, Voi M (1996): Activity of gemcitabine in patients with non-small cell lung cancer: a multicentre, extended phase II study. Eur J Cancer: Feb;32A(2): pp. 243-248. PMID: 8664035

Grossman HB, Natale RB, Tangen CM, Speights VO, Vogelzang NJ, Trump DL, deVere White RW, Sarosdy MF, Wood DP Jr, Raghavan D, Crawford ED (2003): Neoadjuvant chemotherapy plus cystectomy compared with cystectomy alone for locally advanced bladder cancer. N Engl J: Aug 28;349(9): pp. 859-866. PMID: 12944571

Hahn NM, Stadler WM, Zon RT, Waterhouse D, Picus J, Nattam S, Johnson CS, Perkins SM, Waddell MJ, Sweeney CJ; Hoosier Oncology Group (2011): Phase II trial of 
cisplatin, gemcitabine, and bevacizumab as first-line therapy for metastatic urothelial carcinoma: Hoosier Oncology Group GU 04-75. J Clin Oncol: Apr 20;29(12): pp. 1525-1530. PMID: 21422406

Hussain MH, MacVicar GR, Petrylak DP, Dunn RL, Vaishampayan U, Lara PN Jr, Chatta GS, Nanus DM, Glode LM, Trump DL, Chen H, Smith DC; National Cancer Institute (2007): Trastuzumab, paclitaxel, carboplatin, and gemcitabine in advanced human epidermal growth factor receptor-2/neu-positive urothelial carcinoma: results of a multicenter phase II National Cancer Institute trial. J Clin Oncol: Jun 1;25(16): pp. 2218-2224. Erratum in: J Clin Oncol: 2008 Jul 1;26(19): pp. 3295. PMID: 17538166

Jemal A, Murray T, Samuels A, Ghafoor A, Ward E, Thun MJ (2003): Cancer statistics, 2003. CA Cancer J Clin: Jan-Feb;53(1):pp. 5-26. PMID: 12568441

Jemal A, Siegel R, Ward E, Hao Y, Xu J, Murray T, Thun MJ (2008): Cancer statistics, 2008. CA Cancer J Clin: Mar-Apr;58(2): pp. 71-96. PMID: 18287387

Kuroda M, Kotake T, Akaza H, Hinotsu S, Kakizoe T (1998):Efficacy of dose-intensified MEC (methotrexate, epirubicin and cisplatin) chemotherapy for advanced urothelial carcinoma: a prospective randomized trial comparing MEC and M-VAC (methotrexate, vinblastine, doxorubicin and cisplatin). Japanese Urothelial Cancer Research Group. Jpn J Clin Oncol: Aug;28(8): pp. 497-501. PMID: 9769784

Loehrer PJ Sr, Einhorn LH, Elson PJ, Crawford ED, Kuebler P, Tannock I, Raghavan D, Stuart-Harris R, Sarosdy MF, Lowe BA, et al (1992): A randomized comparison of cisplatin alone or in combination with methotrexate, vinblastine, and doxorubicin in patients with metastatic urothelial carcinoma: a cooperative group study. J Clin Oncol: Jul;10(7): pp. 1066-1073. Erratum in: J Clin Oncol 1993 Feb;11(2): pp. 384. PMID: 1607913

Moore M (1996): Activity of gemcitabine in patients with advanced pancreatic carcinoma. A review. Cancer: Aug 1;78(3 Suppl): pp. 633-638. Review. PMID: 8681302

Peters GJ, Bergman AM, Ruiz van Haperen VW, Veerman G, Kuiper CM, Braakhuis BJ (1995): Interaction between cisplatin and gemcitabine in vitro and in vivo. Semin Oncol: Aug;22(4 Suppl 11): pp. 72-79. PMID: 7481849

Saad A, Hanbury DC, McNicholas TA, Boustead GB, Morgan S, Woodman AC (2002): A study comparing various noninvasive methods of detecting bladder cancer in urine. BJU Int: Mar;89(4): pp. 369-373. PMID: 11872026

Saxman SB, Propert KJ, Einhorn LH, Crawford ED, Tannock I, Raghavan D, Loehrer PJ Sr, Trump D (1997): Long-term follow-up of a phase III intergroup study of cisplatin alone or in combination with methotrexate, vinblastine, and doxorubicin in patients with metastatic urothelial carcinoma: a cooperative group study. J Clin Oncol: Jul;15(7): pp. 2564-2569. PMID: 9215826

Sengeløv L, Kamby C, Lund B, Engelholm SA (1998): Docetaxel and cisplatin in metastatic urothelial cancer: a phase II study. J Clin Oncol: Oct;16(10): pp. 3392-3397. PMID: 9779718

Sherif A, Holmberg L, Rintala E, Mestad O, Nilsson J, Nilsson S, Malmström PU; Nordic Urothelial Cancer Group. (2004): Neoadjuvant cisplatinum based combination chemotherapy in patients with invasive bladder cancer: a combined analysis of two Nordic studies. Eur Urol: Mar;45(3): pp. 297-303. PMID: 15036674

Smith DC, Mackler NJ, Dunn RL, Hussain M, Wood D, Lee CT, Sanda M, Vaishampayan U, Petrylak DP, Quinn DI, Beekman K, Montie JE. (2008): Phase II trial of paclitaxel, 
carboplatin and gemcitabine in patients with locally advanced carcinoma of the bladder. J Urol: Dec;180(6): pp. 2384-2388; discussion pp. 2388. Epub 2008 Oct 18.

Soloway MS, Sofer M, Vaidya A (2002): Contemporary management of stage T1 transitional cell carcinoma of the bladder. J Urol: Apr;167(4): pp. 1573-1583. PMID: 18930256

Stadler WM, Kuzel T, Roth B, Raghavan D, Dorr FA (1997): Phase II study of single-agent gemcitabine in previously untreated patients with metastatic urothelial cancer. $J$ Clin Oncol: Nov;15(11): pp. 3394-3398. PMID: 9363871

Sternberg CN, Yagoda A, Scher HI, Watson RC, Herr HW, Morse MJ, Sogani PC, Vaughan ED Jr, Bander N, Weiselberg LR, et al (1988): M-VAC (methotrexate, vinblastine, doxorubicin and cisplatin) for advanced transitional cell carcinoma of the urothelium. J Urol: Mar;139(3): pp. 461-469. PMID: 3343727

Sternberg CN, Yagoda A, Scher HI, Watson RC, Geller N, Herr HW, Morse MJ, Sogani PC, Vaughan ED, Bander N, et al (1989): Methotrexate, vinblastine, doxorubicin, and cisplatin for advanced transitional cell carcinoma of the urothelium. Efficacy and patterns of response and relapse. Cancer: Dec 15;64(12): pp. 2448-2258. PMID: 2819654

Sternberg CN (2000): Gemcitabine in bladder cancer. Semin Oncol: Feb;27(1 Suppl 2): pp. 3139. Review. PMID: 10697034

Sweeney CJ, Roth BJ, Kabbinavar FF, Vaughn DJ, Arning M, Curiel RE, Obasaju CK, Wang Y, Nicol SJ, Kaufman DS (2006): Phase II study of pemetrexed for second-line treatment of transitional cell cancer of the bladder. J Clin Oncol: Jul 20;24(21): pp. 3451-3457. PMID: 16849761

Uhm JE, Lim HY, Kim WS (2007): Paclitaxel with cisplatin as salvage treatment for patients with previously treated advanced transitional cell carcinoma of the urothelial tract. Neoplasia: Jan;9(1): pp. 18-22. PMID: 17325740

Vaishampayan U (2009): Systemic therapy of advanced urothelial cancer. Curr Treat Options Oncol: Aug;10(3-4): pp. 256-266. Epub 2009 Apr 29. Review. PMID: 19408129

Vaishampayan UN, Faulkner JR, Small EJ, Redman BG, Keiser WL, Petrylak DP, Crawford ED (2005): Phase II trial of carboplatin and paclitaxel in cisplatin-pretreated advanced transitional cell carcinoma: a Southwest Oncology Group study. Cancer: Oct 15;104(8): pp. 1627-1632. PMID: 16138364

Van Echo DA, Egorin MJ, Aisner J (1989): The pharmacology of carboplatin. Semin Oncol: Apr;16(2 Suppl 5): pp. 1-6. Review. PMID: 2655093

von der Maase H, Hansen SW, Roberts JT, Dogliotti L, Oliver T, Moore MJ, Bodrogi I, Albers P, Knuth A, Lippert CM, Kerbrat P, Sanchez Rovira P, Wersall P, Cleall SP, Roychowdhury DF, Tomlin I, Visseren-Grul CM, Conte PF (2000): Gemcitabine and cisplatin versus methotrexate, vinblastine, doxorubicin, and cisplatin in advanced or metastatic bladder cancer: results of a large, randomized, multinational, multicenter, phase III study. J Clin Oncol: Sep;18(17): pp. 3068-3077. PMID: 11001674

Winquist E, Kirchner TS, Segal R, Chin J, Lukka H (2004): Neoadjuvant chemotherapy for transitional cell carcinoma of the bladder: a systematic review and meta-analysis. $J$ Urol: Feb;171(2 Pt 1): pp. 561-569. PMID: 14713760

Witte RS, Elson P, Khandakar J, Trump DL. (1994): An Eastern Oncology Group phase II trial of trimetrexate in the treatment of advanced urothelial carcinoma. Cancer: Feb 1;73(3): pp. 688-691. PMID: 8299090

Xu N, Zhang XC, Xiong JP, Fang WJ, Yu LF, Qian J, Zhang L (2007): A phase II trial of gemcitabine plus carboplatin in advanced transitional cell carcinoma of the urothelium. BMC Cancer: Jun 9;7: pp. 98. PMID: 17559681 


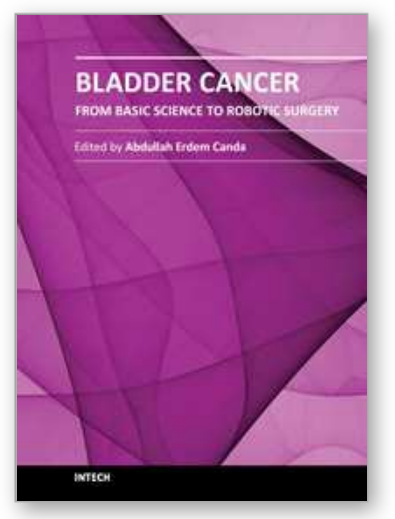

\author{
Bladder Cancer - From Basic Science to Robotic Surgery \\ Edited by Dr. Abdullah Canda
}

ISBN 978-953-307-839-7

Hard cover, 460 pages

Publisher InTech

Published online 01, February, 2012

Published in print edition February, 2012

This book is an invaluable source of knowledge on bladder cancer biology, epidemiology, biomarkers, prognostic factors, and clinical presentation and diagnosis. It is also rich with plenty of up-to-date information, in a well-organized and easy to use format, focusing on the treatment of bladder cancer including surgery, chemotherapy, radiation therapy, immunotherapy, and vaccine therapy. These chapters, written by the experts in their fields, include many interesting, demonstrative and colorful pictures, figures, illustrations and tables. Due to its practicality, this book is recommended reading to anyone interested in bladder cancer.

\title{
How to reference
}

In order to correctly reference this scholarly work, feel free to copy and paste the following:

Takehiro Sejima, Shuichi Morizane, Akihisa Yao, Tadahiro Isoyama and Atsushi Takenaka (2012). Chemotherapy for Metastatic Disease, Bladder Cancer - From Basic Science to Robotic Surgery, Dr. Abdullah Canda (Ed.), ISBN: 978-953-307-839-7, InTech, Available from: http://www.intechopen.com/books/bladdercancer-from-basic-science-to-robotic-surgery/chemotherapy-for-metastatic-disease

\section{INTECH}

open science | open minds

\section{InTech Europe}

University Campus STeP Ri

Slavka Krautzeka 83/A

51000 Rijeka, Croatia

Phone: +385 (51) 770447

Fax: +385 (51) 686166

www.intechopen.com

\section{InTech China}

Unit 405, Office Block, Hotel Equatorial Shanghai

No.65, Yan An Road (West), Shanghai, 200040, China

中国上海市延安西路65号上海国际贵都大饭店办公楼 405 单元

Phone: +86-21-62489820

Fax: +86-21-62489821 
(C) 2012 The Author(s). Licensee IntechOpen. This is an open access article distributed under the terms of the Creative Commons Attribution 3.0 License, which permits unrestricted use, distribution, and reproduction in any medium, provided the original work is properly cited. 